\title{
Botulismul iatrogen - posibilă cauză de slăbiciune generalizată la copil
}

\author{
Mirela Silvia Iancu ${ }^{1,2}$, Luminița Elena Spătariu ${ }^{1,2}$, Victoria Hurduc ${ }^{1,2}$, Doina Anca Pleșca ${ }^{1,2}$ \\ ${ }^{1}$ Disciplina Pediatrie, Universitatea de Medicină şi Farmacie „Carol Davila“, Bucureşti, România \\ ${ }^{2}$ Spitalul Clinic de Copii „Dr. Victor Gomoiu“, Bucureşti, România
}

\begin{abstract}
Abrevieri
$\mathrm{TB}=$ toxină botulinică

$\mathrm{VG}=$ vârsta gestațională

$\mathrm{Gn}=$ greutate la naștere

$\mathrm{OMA}=$ otită medie acută

GMFCS (the gross motor function classification system $)=$ sistemul de clasificare a functiei motorii grosiere
\end{abstract}

\section{REZUMAT}

Botulismul iatrogen este o complicație rară, dar severă a tratamentului cu toxină botulinică, atât la adult, cât și la copil. Articolul prezintă cazul unui copil în vârstă de 5 ani, diagnosticat cu paralizie cerebrală infantilă, tetrapareză spastică și tulburare globală a dezvoltării predominant motorie severă, care, după circa 1 săptămână de la injectarea de toxină botulinică la nivelul membrelor inferioare, prezintă slăbiciune musculară generalizată, cu dificultate în menținerea poziției ridicate a capului, a poziției șezând, ptoză palpebrală, dificultăți de vorbire și alimentare, simptomatologie care s-a remis progresiv în circa 8 săptămâni.

Cuvinte cheie: toxină botulinică, botulism iatrogen, paralizie cerebrală, copil

\section{INTRODUCERE}

Toxina botulinică (TB) este folosită de mult timp în tratamentul diferitelor afecțiuni neuromusculare (atât la indicația producătorilor, cât și off-label) cum ar fi distonie, spasticitate, torticolis spasmodic, blefarospasm, spasm hemifacial, strabism. În ultimii ani, utilitatea sa s-a extins și în aplicații cosmetice (terapie de întinerire sau hiperhidroză), terapia durerii cronice din migrenă, sialoree, tulburările urinare ale vezicii neurogene sau nonneurogene. În țara noastră, utilizarea abobotulinumtoxinei A (Dysport) la copiii cu paralizie cerebrală este autorizată doar pentru deformarea dinamică - picior equin, de la vârsta de 2 ani.
Doza de toxină botulinică A indicată la pacienții pediatrici cu paralizie cerebrală pentru reducerea spasticității la membrele inferioare nu este clar specificată. Aceasta trebuie individualizată și estimată în funcție de musculatura implicată, gradul spasticității, istoricul injectărilor și răspunsul sau reacțiile adverse obținute la administrările anterioare. Totuşi, se recomandă să nu se depășească doza de 10-15 U/kg pentru un membru sau 20-30 U/kg pentru injectarea ambelor membre inferioare sau $1000 \mathrm{U}$ (se va alege doza mai mică) la o ședință. Doza trebuie împărțită între mușchii afectați și, când e posibil, distribuită prin mai multe injectări într-un mușchi (1). Administrările trebuie sa fie spațiate la minimum 12 săptămâni interval. 


\section{PREZENTARE DE CAZ}

Fetiță, în vârstă de 5 ani, diagnosticată cu paralizie cerebrală și tetrapareză spastică, efectuează toxina botulinică tip A (Dysport) pentru spasticitatea membrelor inferioare. După aproximativ 1 săptămână de la injectare, începe să prezinte astenie, slăbiciune musculară generalizată, cu imposibilitatea de a-și ține capul și a menține poziția șezând, mișcări active spontane reduse, ptoză palpebrală dreaptă, dizartrie, tulburări de deglutiție și dificultăți de alimentare, vorbire încetinită și neclară, scurgerea secrețiilor salivare din cavitatea bucală.

Copilul provine din sarcină nedispensarizată, născută spontan la vârsta gestațională de 26 săptămâni, cu greutatea la naștere de $995 \mathrm{~g}$ și scor APGAR 4 la 1 minut și 8 la 5 minute. În a 3-a zi de viață, prezintă hemoragie intraventriculară cu anemie severă, pentru care primește 5 transfuzii de sânge. În ziua a 9-a de viață, se stabilește diagnosticul de sepsis, motiv pentru care se inițiază antibioterapie și nutriție parenterală totală. Din cauza hidrocefaliei interne posthemoragice, s-au impus puncții ventriculare repetate, iar la vârsta de 5 luni se montează șunt ventriculoperitoneal. Întrucât în evoluție se constată infecție de șunt cu Pseudomonas și stafilococ, se impune îndepărtarea acestuia. După 1 lună de tratament antibiotic și antimicotic, se montează un șunt subgaleal, care a prezentat din nou disfuncții care vor impune puncționare și revizuire în 2 rânduri pentru ca, la vârsta de 9 luni, să fie înlocuit de un șunt ventriculoperitoneal. Ulterior acestei intervenții, evoluția este favorabilă. În cadrul programului de recuperare, copilul a efectuat masaj și kinetoterapie încă de la vârsta de sugar, precum şi recuperare nutrițională. La vârsta de 1 an și 3 luni, este preluată de un centru de îngrijire pentru copii cu dizabilități severe. Din acel moment, copilul a avut o evolutie favorabilă, fără complicații neurochirurgicale și doar 2 internări în secție ORL pentru otită medie acută (OMA).

La vârsta de 5 ani şi 2 luni, s-a efectuat pentru prima dată terapie decontracturantă cu toxină botulinică (TB). La acel moment, diagnosticul copilului era de întârziere severă a dezvoltării motorii (GMFCS V), spasticitate marcată pe adductorii coapsei și triceps sural, dar de precizat că se ridica singură în șezut, se rostogolea, stătea în 4 membre, le alterna cu dificultate. Limbajul expresiv era prezent. S-a decis injectarea de toxină botulinică tip A (doză neprecizată) atât în membrele superioare, cât și în cele inferioare, tratament bine tolerat, fără reacții adverse, și s-a continuat kinetoterapia. După 4 luni, se administrează din nou Dysport în doză de 1.000 UI, de data aceasta doar la nivelul membrelor inferioare și s-au continuat kineto- terapia și ergoterapia. După 1 săptămână, se instalează progresiv slăbiciune musculară generalizată, ptoză palpebrală dreaptă, apar dificultăți în alimentare, cu imposibilitatea de a înghiți alimente solide și cu vorbire lentă. În a 12-a zi după tratamentul inițiat cu TB, copilul prezintă febră și o vărsătură, ulterior rinoree moderată și tuse rară. Se efectuează CT cerebral și consult neurochirurgical, care au exclus o cauză legată de șunt. Este internată la spital de boli infecțioase, unde se efectuează puncție lombară, cu ajutorul cărei se exclude meningita acută. Se stabilește diagnosticul de pneumonie acută interstițială cu VSR și se inițiază terapia. Este reevaluată neuromotor la 3 săptămâni de la injectarea de TB, iar electromiograma single-fiber (EMGSF) arată jitter crescut și timp de latență prelungit la nivelul joncțiunii neuromusculare. Pe baza datelor clinice şi electrofiziologice (EMG), se ridică suspiciunea de botulism. Simptomatologia apărută se reduce lent, progresiv și dispare complet după aproximativ 8 săptămâni. Urmare acestui eveniment, se întrerupe administrarea de TB, copilul continuând doar programul de ergo şi kinetoterapie.

\section{DISCUTुII}

Există 8 serotipuri distincte $(\mathrm{A}, \mathrm{B}, \mathrm{C} 1, \mathrm{C} 2, \mathrm{D}, \mathrm{E}, \mathrm{F}$ şi G) de neurotoxină produse de Clostridium botulinum, bacil gram pozitiv anaerob recunoscut drept agent etiologic al botulismului încă din 1897 (2). Proprietățile farmacologice ale acestora sunt diferite, iar pentru uz clinic sunt disponibile doar două: tipul A, cu utilitatea cea mai largă, și, mai puțin, B.

Acțiunea toxinei botulinice are loc la nivelul terminațiilor nervoase colinergice presinaptice, unde blochează eliberarea acetilcolinei în fanta sinaptică și împiedică contracția musculară (chemodenervare) (Fig. 1). Efectul inhibitor al toxinei durează aproximativ 3 luni, iar functia sinapsei se reia prin plasticitate și remodelare, adică formarea de căi noi dar tranzitorii colaterale axonale (sprouting), care asigură inervația mușchiului până la reluarea funcției terminației neuronale iniţiale (3).

Terapia cu TB este o metodă relativ sigură și bine tolerată (4), cu reacții adverse rare, de obicei ușoare și tranzitorii, cum ar fi durerea locală sau apariția unor infecții de căi respiratorii superioare (CRS), caracterizate prin obstrucție nazală și rinoree, durere în gât, tuse și febră. Efectele sistemice, precum anafilaxia și simptomele flu-like, sunt rare și, posibil, mediate imun. Difuzarea sistemică a toxinei poate duce însă la botulism iatrogen, o subformă de botulism potențial fatală, manifestată clinic prin slăbiciune musculară generalizată, insuficiență velo-faringiană cu dizartrie, disfonie, disfagie, manifestări oculare cu ptoză palpe- 


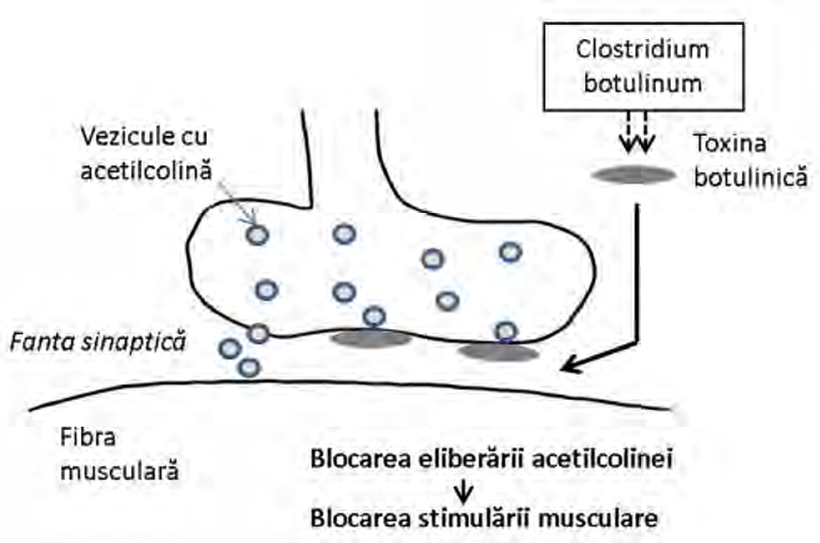

FIGURA 1. Mecanismul de acțiune al toxinei botulinice

brală, diplopie, detresă respiratorie, incontinență urinară. Nu se cunoaște exact mecanismul de difuzare a toxinei botulinice, dar sunt considerate posibile atât răspândirea sistemică, cât și transportul axonal retrograd al acesteia către sistemul nervos central. Reacțiile adverse par a se corela nu atât cu doza raportată la kilogramele pacientului, cât cu doza totală administrată la o ședință (5). Iarăşi, în mod interesant, aceste reacții adverse sistemice pot apărea atât după administrări repetate de TB, cât și la prima administrare, la doze terapeutice, dar chiar și la doze mai mici, la interval de ore sau săptămâni de la injectare, făcând greu de prezis pacienții cu risc potențial (6). Au fost situații în care la acești pacienți s-a întrerupt tratamentul cu TB sau s-a continuat acest tratament, iar pacientul nu a repetat reacțiile adverse severe la distanță. La pacienții cu boli neuromusculare sau aflaţi în tratament cu aminoglicozide, efectul administrării parenterale de toxină botulinică poate fi potențat și trebuie urmărit cu atenție. De asemenea, este contraindicată administrarea la cei cu alergie la proteinele din laptele de vacă sau reacții alergice la o injectare anterioară de TB.

Studiile electrofiziologice reprezintă un ajutor util în confirmarea diagnosticului de botulism iatrogen, deși în literatură sunt puține raportări și acestea sunt heterogene. Nu există un model cu specificitate înaltă, diagnosticul bazându-se pe manifestările clinice și datele anamnestice. Totuşi, trebuie subliniat că modificările EMG de denervare acută sunt considerate cele mai sugestive anomalii în botulismul iatrogen (7).

La copii s-au raportat mai puține cazuri de acest fel comparativ cu adulții, TB fiind în general bine tolerată (8). În cazul a 882 de copii tratați cu TB pentru spas-

\section{BIBLIOGRAFIE}

1. https://reference.medscape.com/drug/dysportabobotulinumtoxina-999220.

2. Nigam PK, Nigam A. Botulinum toxin. Indian J Dermatol. 2010; 55(1):8-14 ticitate secundară paraliziei cerebrale $(\mathrm{PC})$, reacțiile adverse au fost în principal de tip infecții de tract respirator, bronșite, faringite și mai puțin slăbiciune musculară și cădere (9). Willis și colaboratorii (10) nu au găsit diferențe semnificative statistic în apariția reacțiilor adverse după injectarea de TB în doze mai mari sau mai mici la copiii cu PC, indiferent de etiologia PC, tipul de afectare motorie, severitate a bolii, abilitatea funcțională sau medicația folosită, spre deosebire de Swinney și colaboratorii, care arată că pacienții cu forme severe de PC (GMFCS IV şi V) prezintă risc mai mare de reacții adverse sistemice (11). Un review care a cuprins 758 de pacienți cu vârsta medie de 7,2 ani, cu un total de 1594 injecții de TB pentru spasticitate, arată că dozele mai mari de 1.000 UI nu aduc un răspuns terapeutic mai bun și cresc riscul pentru reacții adverse (5). De fapt, studiile controlate randomizate nu evidențiază efectele adverse severe sau pe termen lung ale TB, acestea fiind aflate, mai degrabă, din raportările spontane de cazuri (12-14).

\section{CONCLUZII}

Cazul prezentat se poate înscrie într-o serie de raportări de reacții adverse la distanță, mai mult sau mai puțin severe, survenite postinjectare de TB. La acest pacient, injectarea s-a efectuat la nivelul membrelor inferioare, după care, la circa 1 săptămână, s-a instalat progresiv slăbiciune musculară generalizată, cu efecte anticolinergice la nivelul extremității cefalice (orofaringiene și oculare), fără insuficiență respiratorie, slăbiciune care nu a impus tratament și s-a remis progresiv în circa 2 luni. Particularitatea cazului constă în asocierea și a unui episod de infecție de căi respiratorii inferioare, manifestare descrisă ca posibilă rară reacție adversă la TB. La copiii încadrați în GMFCS $\mathrm{V}$, ca şi pacienta noastră, adică cu hipertonie generalizată, la care spasticitatea constituie doar o componentă a afecțiunii, indicațiile tratamentului cu TB care vizează tonusul focal sunt mai greu de definit, iar rezultatele sunt mai puțin predictibile. Deși aceste reacții sunt rare, dar imprevizibile, este indicată o urmărire atentă a pacienților care efectuează astfel de tratamente. De asemenea, este util ca familia și persoanele implicate în îngrijirea acestor copii să fie avizate de posibilitatea apariției acestor reacții adverse.

Conflict of interest: none declared Financial support: none declared

3. de Paiva A, Meunier FA, Molgo J, Aoki KR, Dolly JO. Functional repair of motor endplates after botulinum neurotoxin type A poisoning: biphasic switch of synaptic activity between nerve sprouts and their parent terminals. Proc Natl Acad Sci USA. 1999;96(6):3200-5. 
4. Nauman M, Albanese A, Heinen F, Molenaers G, Relja M. Safety and efficacy of toxin type A following longterm use. Eur J Neurol. 2006; 13(Suppl. 4): 35-40.

5. Bakheit AM, Severa S, Cosgrove A, Morton R, Roussounis SH, Doderlein $L$ Safety profile and efficacy of botulinum toxin $A$ (Dysport) in children with muscle spasticity. Dev Med Child Neurol. 2001; 43(4):234-238.

6. Phadke CP, Balasubramanian CK, Holz A, et al. Adverse clinical effects of botulinum toxin intramuscular injections for spasticity. Can J Neurol Sci. 2016;43(2):298-310.

7. Leonardi L, Haggiag S, Petrucci A, Lispi L. Electrophysiological abnormalities in iatrogenic botulism: Two case reports and review of the literature. J Clin Neurosci. 2019;60:138-141.

8. Delgado MR, Tilton A, Russman B, Benavides O, Bonikowski M, Carranza J, Dabrowski E, Dursun N, Gormley M, Jozwiak M, Matthews D, Maciag-Tymecka I, Unlu E, Pham E, Tse A, Picaut P. AbobotulinumtoxinA for Equinus Foot Deformity in Cerebral Palsy: A Randomized Controlled Trial. Pediatrics. 2016;137(2):e20152830.

9. Albavera-Hernandez C, Rodriguez JM, Idrovo AJ. Safety of botulinum toxin type A among children with spasticity secondary to cerebral palsy: a systematic review of randomized clinical trials. Clinical Rehabilitation 2009;23(5):394-407.
10. Willis AW, Crowner B, Brunstrom JE, Kissel A, Racette BA. High dose botulinum toxin $A$ for the treatment of lower extremity hypertonicity in children with cerebral palsy. Dev Med Child Neurol. 2007; 49(11):818-822.

11. Swinney CM, Bau K, Burton KLO, O'Flaherty SJ, Bear NL, Paget SP. Severity of cerebral palsy and likelihood of adverse events after botulinum toxin A injections. Dev Med Child Neurol. 2018; 60(5):498-504.

12. Crowner BE, Torres-Russotto D, Carter AR, Racette BA. Systemic weakness after therapeutic injections of botulinum toxin a: a case series and review of the literature. Clin Neuropharmacol. 2010; 33(5):243-247.

13. Bhatia KP, Münchau A, Thompson PD, et al. Generalised muscular weakness after botulinum toxin injections for dystonia: a report of three cases. Journal of Neurology, Neurosurgery \& Psychiatry 1999;67:90-93.

14. Yiannakopoulou E. Serious and long-term adverse events associated with the therapeutic and cosmetic use of botulinum toxin. Pharmacology. 2015;95(1-2):65-9. 